\title{
Impact of Fair Value Accounting on Biological Assets in Agricultural Sector in Nigeria
}

\author{
Ubesie Madubuko Cyril ${ }^{1, ~}$, Nnajieze Ifeyinwa Elizabeth ${ }^{1}$, Mbah Chris Chukwuemeka ${ }^{2}$ \\ ${ }^{1}$ Department of Accountancy, Faculty of Management Sciences, Enugu State University of Science and Technology (ESUT), Enugu, Nigeria \\ ${ }^{2}$ Department of Marketing, Faculty of Management Sciences, Enugu State University of Science and Technology (ESUT), Enugu, Nigeria
}

\section{Email address:}

ubesiemadubuko@yahoo.com (U. M. Cyril)

${ }^{*}$ Corresponding author

\section{To cite this article:}

Madubuko Cyril Ubesie, NnajiezeIfeyinwa Elizabeth, Mbah Chris Chukwuemeka. Impact of Fair Value Accounting on Biological Assets in Agricultural Sector in Nigeria. International Journal of Finance and Banking Research. Vol. 5, No. 4, 2019, pp. 64-70. doi: 10.11648/j.ijfbr.20190504.11

Received: May30, 2019; Accepted: July 17, 2019; Published: August 5, 2019

\begin{abstract}
This study critically reviewed the impact of fair value accounting on biological assets of Nigerian agricultural sector with a focus on Okomu Oil Palm Company Plcfor the period of 2009-2018. The study adopted ex-post facto research design. Analytical techniques employed were descriptive statistics and Ordinary Least Squares (OLS) multiple regression analysis. Findings revealed that fair value accounting operationalized by non-current asset, profit after tax, and current assets have insignificant positive effect on the biological assets of the Nigerian Agricultural firms. The implication is that the company reports gain in their biological assets when the fair values of their assets increases. Based on these findings, it was recommended among others that there is need for agricultural firms to adopt the fair value accounting system in other to keep proper records of its biological assets.
\end{abstract}

Keywords: Fair Value, Biological Assets, Ordinary Least Squares Regression, Agricultural Sector

\section{Introduction}

Fair value measurement of assets and liabilities is one of the controversial topics in financial reporting; with the agricultural sector not an exception. Until the adoption of International Accounting Standard (IAS) 41 in 2003 which establishes the accounting treatment with respective disclosure for biological assets and agricultural products, less concern has been paid by researchers and accounting standard regulators on accounting for agricultural activities [1] due to its relative lack of importance to the global economy.In reaction to this, GonçalvesandLopes (2014) noted that before the adoption of IAS, current accounting principles had not been responding maximally tosome characteristics of agriculturalbusinesses and the information needs of farmers and their stakeholders, thereby resulting to poor performance of the sector [2].

According to Ryan (2008), fair value accounting is required to measure and report on an ongoing basis, certain assets and liabilities (generally financial instruments) at estimates of the prices they would receive if they were to sell the assets or would pay if they were to be relieved of the liabilities [3]. It is the amount for which an asset could be exchanged, a liability settled, or an equity instrument granted between knowledgeable, willing parties in an arm's length transaction. Simply put, it is the market price for asset based on current expectations [4-6]; and involves approaches to financial reporting whereby profits are measured by comparing revenue with the current replacement cost of the assets consumed in the earning process. This implies that, under fair value accounting, companies report losses when the fair values of their assets decrease or liabilities increase. Those losses reduce companies' reported equity and may also reduce companies' reported net income [7].

Consequently, fair value accounting recognizes in the income statement, the cost which a going concern actually has to pay to replace its expiring assets [5]. Adoption of fair value is explained by information asymmetry, contractual efficiency and managerial opportunism [8]. Particularly, the use of fair value for some specific assets is justified. Hence, items that are subject to great volatility in market prices, such as biological 
assets, which are also subject to great alterations in their physical characteristics, must be evaluated by fair value so as to reflect the company's economic situation more faithfully.

Depending on accounting standards of the country, agricultural products are valued at fair value or historical costs [9]. Hence, it constitutes a hypothetical market price under idealized market environment. Assets from these agricultural products are referred to as biological assets; for instance, living animals and plants which are a part of agricultural activity of the company [5]. Particularly, the International Accounting Standard 41 (IAS 41) states that biological assets are living plant or animals owned by the business, and are typically measured at fair value minus selling costs [10]. They include livestock such as goats, cows, sheep, pigs, and fish, crops and vegetables grown by farmers - corn, tomatoes - as well as grapevines, cannabis, trees, and any produce coming from trees, such as apples.

Biological assets can be held and accounted for by any business owner. They generate substantial revenue or income for businesses. However, because of their nature, they are typical of utmost importance to farmers or any individuals whose primary source of profit comes from growing, selling, and shipping such goods. More so, because they are living and have active component that makes them difficult to maintain, biological assets are frequentlyunder the threat of change, (qualitative and quantitative). These changes are widely known or understood outside of the business scope as biological changes. It simply means that plants, animals, and the living things they produce (such as hens producing eggs or cows producing milk) have a period of time where they must grow or be produced, a useful period during which they can be harvested, and a limited amount of time during which they can be moved and sold before they rot, decay, or otherwise, become useless to consumers.

Biological assets are typically seen in the balance sheet of companies. They are unique to the field of accounting for the purpose of clearly categorizing and identifying assets owned by businesses, such as farms and vineyards, or produce that is a primary source of the company's income. Importantly, businesses in various industries and sectors can raise plants and animals for a variety of reasons; classifying them as biological assets denotes their nature and value to the business owner.

Biological assets are subject to high market price fluctuations resulting from the influence of the economy, climate, diseases, pests, etc. More so, previous discussions on fair value valuation have gathered critics and defenders. Some parties believe that fair value accounting benefits investors while others believe it hurts investors. This study however, critically analyzed the impact of fair value accounting on biological assets in Nigeria with a special focus to Nigerian agricultural sector. The study takes cognizance of the three tiered hierarchy inputs as prescribed by Grant (2008) in Bessong and Charles (2012) [11], Level 1 inputs which are based upon quoted market prices for identical assets and liabilities in active markets. Level 2 inputswhich are quoted prices from sources other than level
1, such as an interest rate swap which utilizes observable data points like the yield on treasury bonds; and Level 3 inputswhich are unobservable assumptions, such as an entity's internal valuation model, that incorporates management assumptions that cannot be corroborated with observable market data. Bearing in mind previous studies, this present study offers an in-depthknowledge on the subject matter. The study is structured as follows: Section 2 provides a literature review of related studies; Section 3 describes the methodology, Section 4is data analysis and discussion of results while section 5provides the conclusion and make necessary recommendations.

\section{Review of Empirical Literature}

In view of the difficulty in adopting the International Accounting Standard (IAS) 41, which determines the measurement of biological assets, Cavalheiro, Kremer and Gimenes (2017) employedthe fair-value based methodology to quantitatively evaluate the biological assetsof soybean crop cultivated in the MatoGrosso do Sul State for the periods of 2005-2016 [12]. The study utilized Discounted Cash Flow (DCF) evaluation method and suggests that agronomic knowledge should be considered in addition to economic methods in evaluating biological assets in quantitative and qualitativeterms.

Starova et al (2016) investigated the applicability of International Accounting Standard (IAS) 41 to the valuation of a growing stock of stands and entering its value in the corporate accounting system in the Czech Republic [13]. The study used a sample of 317 respondents in the period from $1^{\text {st }}$ of March 2015 to $30^{\text {th }}$ of June 2015. Findings revealed that there is an increasing tendency towards the willingness to report the forest in the statements, especially in the organizations which simultaneously meet the statutory duty to disclose this value in the notes to the statements, and it is also recognized that this willingness does not depend on the legal form of organization.

Dorel, et al (2015) examined the incompatibility of the recognition and assessment criteria of agriculture production, biological assets and agriculture products imposed by the application of these standards in agro-food companies, and to analyze its effects concerning the financial position and performance of these entities [14]. The result revealed that the conflictsbetween the national Romanian accountingnorms and IAS 41 are because agro-food companiesreduce the importance of measurementunder the historical cost in favour of the fair value.

The study of Biljon (2016) focused on ways to improving consistency in fair value of biological assets [15]. The study used inductive content analysis using annual reports of 50 organizations on the financial affairs from 2012 to 2014. Analytical method employed was the grounded theory with the use of coding and flowcharts. Findings revealed that through the detailed testing performed in the various research phases it was reconfirmed that even though smaller organizations do not publish their financial statements listed 
organizations demonstrated the same deficiency while detailed information is not included in the annual reports to allow users to assess the performance of the organization or to compare the financial results to that of other organizations. It was also confirmed that financial reports on the 2014 and 2015 financial years were more comprehensive than that of previous years, which is a confirmation that there is an increased focus on the reporting of comparable and informative financial results.

Balogun (2015) empirically examined the methods of fair value accounting in five petroleum companies listed on the Nigeria Stock Exchange with a view to determining its effect on historical cost method of asset valuation in public limited companies [16]. Data on price level changes (Price Index) of the assets of the companies under review were obtained from Bureau of Statistics as published by the Central Bank of Nigeria while data on Historical values were obtained from the published annual financial statements of the companies. Fair values were determined using the price index whilet-test statistical tool was used in data analysis. Findings revealed that there is a significant difference between assets valued at fair value and historical cost method. Also, the result provided that price level changes was the principal factor responsible for the difference in asset valuation and that financial statements prepared under these methods produced different information for the users.

Bessong and Charles (2012) empirically examined the effects of fair value accounting and historical cost accounting on the reported profits of selected manufacturing companies in Nigeria [11]. The study used secondary data extracted from the companies' annual reports and employed ordinary least square regression analysis techniques. The findings among others provided evidence that both historical cost and fair-value accounting have significant effect on the reported profit of manufacturing firms in Nigeria.

Kazmouz (2010) examined the effect of applying fair value on the financial statements of UK leading companies for the periods of 1990-2009 [17]. The study used a sample of $20 \mathrm{UK}$ companies for the period and segregated the data into pre-fair value application period (1990-2004) and postfair value application period (2005 - 2009). Student's t-test of comparison of means was utilized in the data analysis. Result indicated that property, plant and equipment, net income and return on equity, depreciation and amortization except the intangible assets showed significant results.

Alaryan, Haija and Ali (2014) carried out an empirical investigation on therelationship between fair value accounting and presence of manipulation in financial statements of Jordan companies [18]. The study used a secondary data extracted from annual reports of 45 companiesin Jordan; covering the period from 1997- 2006, five years before and after the application of fair value application. Analytical tools used were logistic regression and Chi-square test. Result provided that fair value application warrants manipulation of accounting figures in the financial statement of firms in Jordan. This implies that the number of firms that manipulated information in the financial statements had increased after applying fair value accounting in Jordan.

Al-Khadash and Khasawneh (2014) examined the effects of applying fair value accounting under IAS 40 on the volatility of earnings [19]. The study majorly focused on how the addition of unrealized gains and losses in the income statement might affect the incremental explanatory power of earnings. Quantitative data were collected from the Jordanian Shareholding Companies listed on Amman Stock Exchange for the period of 2002-2009. The Ohlson valuation model (1995) and the Theil technique (1971) were utilized. Findings revealed that unrealized gains and losses affect the net income while the cross-sectional regression result showed that net income and book values have joint and individualpositive and significanteffect on stock prices in Jordan.

Elfaki and Hammand (2015) empirically investigated the impact of fair value accounting on the quality of accounting information in Khartoum [20]. The study employed analysis of variance (ANOVA) techniques and found that fair value contribute to provide useful information to users of financial statements and help them in decision-making. The study also revealed that there is a positive relationship between the application of fair value and appropriateness of accounting information in decision- making; and a positive relationship between the application of fair value and reliability ofaccounting information in Khartoum. The implication is that the reliability of users, in addition to the fair value, was able to make a fair comparison, both at the enterprise level for a number of periods or with similar enterprises for the same period.

Employing the multiple regression techniques, Al-Sakini and Al-Awawdeh (2015) empirically explored the effect of accounting conservatism and its impacts on the fair value of corporation on Jordanian Public Joint-stock Industrial Companies [21]. The study used a sample of 30 Jordanian corporations for the periods of 2006 - 2013. Results showed that the size of the company's assets and profitability are deemed the most important factors which have positive impact on the fair value of the companies while the ratio of debts impact negatively on the fair value of the company. However, the ratio of profits distribution (dividend payout) and fixed assets was found to exert insignificant effect on the fair value. This showed that it is necessary that the applied principles and rules of fair value accounting should not be made to disregard the principle of caution, which is the safety valve against any unexpected reflections on the asset values and revenues. The excessive reliance on the fair value may result to increase the exposure of companies to market risks and sudden movements of prices.

\section{Methodology}

Ex-post facto design was adopted as the study used existing data that have been collected by the firms, which the researcher can neither manipulate nor control. Annual time series data for the period of 10years (2009-2018) were extracted from annual accounts and financial statement of the selected firms. Descriptive statistics and Ordinary Least Squares (OLS) multiple regression analysis mechanism were 
employed. Diagnostic tests performed include JarqueBeratest of normality of the data series, and Breusch-PaganGodfrey Heteroskedasticity test as recommended by (Gujarati and Porter, 2009). This was to forestall spurious regression analysis; the model is specified thus:

$$
\mathrm{Y}_{1}=\alpha+\beta \mathrm{X}_{\mathrm{t}}+\mathrm{U}_{\mathrm{t}}
$$

Where,

$\mathrm{Y}=$ dependent variable (explained variable)

$\mathrm{X}=$ independent variable (explanatory variable)

$\alpha=$ Constant term (i.e., value of $Y$ when $X$ is zero)

$\beta=$ Coefficient of the parameter estimates

$\mathrm{U}=$ error term (residual term)

The assumption of this model is that:

$$
Y \sim N\left(\theta, \sigma^{2}\right)
$$

Where, $\mathrm{Y}$ is the Dependent (or Response) variable; $\theta$ is the constant or intercept of the regression model, $\sigma^{2}$ is the variances and covariances of the random term.

Explicitly for this study,

$$
\begin{aligned}
\log (B i o A)_{t}=\beta_{O}+ & \beta_{1} \log (N C A)_{t}+\beta_{2} \log (P A T)_{t}+ \\
& \beta_{3} \log (C A)_{t}+\varepsilon_{t},
\end{aligned}
$$

where,

EPS $_{\mathrm{t}}=$ Biological assets of the Company (Dependent variable),

$\mathrm{NCA}_{\mathrm{t}}=$ Fair value non-current asset of the Company (Independent variable),

$\mathrm{PAT}_{\mathrm{t}}=$ Fair value Profit after Tax of the Company (Independent variable),
$\mathrm{CA}_{\mathrm{t}}=$ Fair value current asset of the Company (Independent variable),

$\beta_{0}=$ Constant/intercept of the regression model.

$\beta_{1}, \beta_{2}$, and $\beta_{3}$, are the regression parameters.

$\varepsilon_{t}=$ Random/stochastic error associated with the model. $\mathrm{t}=$ time

Apriori Expectation: $\beta_{i, s}>0$

\section{Data Presentation, Results and Interpretation}

Table 1. Annualized time series data used for the Study.

\begin{tabular}{lllll}
\hline Years & $\begin{array}{l}\text { BioA } \\
\text { (N'000) }\end{array}$ & $\begin{array}{l}\text { NCA } \\
\text { (N'000) }\end{array}$ & $\begin{array}{l}\text { PAT } \\
\text { (N'000) }\end{array}$ & $\begin{array}{l}\text { CA } \\
\text { (N'000) }\end{array}$ \\
\hline 2009 & 824843 & 10092636 & 549410 & 2764346 \\
2010 & 704647 & 15606143 & 1629456 & 3896632 \\
2011 & 15049344 & 18358052 & 10518739 & 5007512 \\
2012 & 21008866 & 25334813 & 8954343 & 5719860 \\
2013 & 19692910 & 26200037 & 2092174 & 3850611 \\
2014 & 34294325 & 30375665 & 1553455 & 619915 \\
2015 & 17244670 & 631436 & 2205065 & 2808515 \\
2016 & 25235609 & 2921542 & 4175601 & 6537647 \\
2017 & 24115209 & 3974591 & 6235123 & 7256943 \\
2018 & 36761472 & 5830900 & 5942910 & 9115139 \\
\hline
\end{tabular}

Source: Annual Report and Financial Statement of Okomu Oil Palm Company Plc (2009-2018)

Where,

BioA $=$ Biological Assets

NCA $=$ Non-current Assets

$P A T=$ Profit after Tax

\begin{tabular}{|c|c|c|c|c|c|}
\hline Variables & Mean & Std. Dev. & Skewness & Kurtosis & $\operatorname{Prob}(\mathrm{JB})$ \\
\hline BioA & 19493190 & 12019719 & -0.307 & 2.277 & 0.8290 \\
\hline $\mathrm{NCA}$ & 13932582 & 10806219 & 0.241 & 1.570 & 0.6221 \\
\hline PAT & 4385628 & 3411209 & 0.630 & 2.058 & 0.5969 \\
\hline $\mathrm{CA}$ & 4757712 & 2491054 & 0.131 & 2.357 & 0.9043 \\
\hline
\end{tabular}

$C A=$ Current Assets

Data Analysis

Table 2. Descriptive Statistics/Normality test result of the variables under study.

\begin{tabular}{|c|c|c|c|c|}
\hline \multicolumn{5}{|c|}{ Sample: 20092018 (10Years) } \\
\hline \multicolumn{5}{|l|}{ Correlation } \\
\hline \multicolumn{5}{|l|}{ t-Statistic } \\
\hline Probability & BioA & NCA & PAT & CA \\
\hline BioA & $\begin{array}{l}1.000000 \\
--- \\
---\end{array}$ & & & \\
\hline $\mathrm{NCA}$ & $\begin{array}{l}0.055119 \\
0.156138 \\
0.8798\end{array}$ & $\begin{array}{l}1.000000 \\
----\end{array}$ & & \\
\hline PAT & $\begin{array}{l}0.270530 \\
0.794812 \\
0.4497\end{array}$ & $\begin{array}{l}0.045008 \\
0.127432 \\
0.9017\end{array}$ & $\begin{array}{l}1.000000 \\
----\end{array}$ & \\
\hline $\mathrm{CA}$ & $\begin{array}{l}0.347767 \\
1.049120 \\
0.3248\end{array}$ & $\begin{array}{l}-0.473599 \\
-1.520923 \\
0.1668\end{array}$ & $\begin{array}{l}0.588827 \\
2.060543 \\
0.0733\end{array}$ & $\begin{array}{l}1.000000 \\
---- \\
---\end{array}$ \\
\hline
\end{tabular}

Source: Researcher's E-views 10.0 Result

Table 3. Correlation/Covariance Analysis.

Source: Researcher's E-views 10.0 Result
The descriptive statistics showing the mean, standard deviation, Skewness, Kurtosis, as well asprob (Jarque-Bera) goodness of fit test indicates that the data series are highly volatile (with high standard deviations). This specifies high level of uncertainty in predictive power of the series. The result also shows that series of biological assets in the company is negative skewed (skewed to the left) while the rest of the variables are positively skewed. There is no excess kurtosis $(K>3)$ in the series and all the sample data have the skewness and kurtosis matching a normal distribution (with $\operatorname{prob}(\mathrm{JB})>0.05)$ within the period.

The correlation and covariance analysis indicates that fair value accounting interacts positively with biological assets of Okomu Oil Palm Company Plc. There was a negative association between current and non-current assets of the company for the period under review indicating that high current asset leads to low non-current asset. These pairwise 
associations were all insignificant ( $\mathrm{p}$-value $>0.05$ ).

Table 4. Residual Diagnostic Results.

\begin{tabular}{lll}
\hline Type of Test & Test statistic & Probability value \\
\hline Residual Normality test & J-B stat. $=0.985$ & 0.6112 \\
Residual Heteroskedasticity test & F-stat $=1.889$ & 0.2324 \\
\hline
\end{tabular}

Source: Author's extract from Eviews 10.0output (2019) [See Appendix A \& B]

The result in table 4 indicates that the residual series are normally distributed and homoscedastic (with p-values $>$ 0.05). This fulfills the basic assumption of Ordinary Least Squares (OLS) regression analysis as specified in equation 3.2. The researcher therefore proceeds to ordinary least squares regression analysis as below.

Table 5. Regression Analysis.

\begin{tabular}{|c|c|c|c|c|}
\hline \multirow[t]{2}{*}{ Variables } & \multicolumn{4}{|c|}{$\begin{array}{l}\text { Method: ARMA Maximum Likelihood (OPG - BHHH) } \\
\text { Dependent Variable: } \log (\text { BioA); Sample: } 2009 \text { - } 2018\end{array}$} \\
\hline & Coefficient & Std. Error & t-stat & Probability \\
\hline Constant & 8.063226 & 18.91359 & 0.426319 & 0.6918 \\
\hline $\log (\mathrm{NCA})$ & 0.040906 & 0.824669 & 0.049603 & 0.9628 \\
\hline $\log (\mathrm{PAT})$ & 1.030236 & 0.625542 & 1.646951 & 0.1749 \\
\hline $\log (\mathrm{CA})$ & -0.518388 & 1.238812 & -0.418456 & 0.6971 \\
\hline \multicolumn{5}{|c|}{ R-squared $=0.744533$} \\
\hline \multicolumn{5}{|c|}{ Adj R-Squared $=0.425199$} \\
\hline \multicolumn{5}{|c|}{ F-Statistics $=2.331516$ Prob $(\mathrm{F}-\mathrm{Stat})=0.216209$} \\
\hline \multicolumn{5}{|c|}{ Durbin-Watson Statistics $=1.522128$} \\
\hline
\end{tabular}

Source: Researcher's E-views 10.0 Result

The multiple regression result in table 4 indicates that fair value of non-current assets and profit after tax have positive effect on biological assets in Okomu Oil Palm Company Plc (with coeff. values of 0.041 and 1.030 respectively); while the effect of fair value current asset on the biological assets of Okomu Oil Palm Company Plc is negative. Particularly, the result revealed that all the explanatory variables have insignificant effect ( $p$-values $>0.05$ respectively). The Fisher statistics $(\mathrm{F}-\mathrm{stat} .=2.332 ; \mathrm{p}=0.2162>0.05)$ equally indicates that the explanatory variables do not exert joint significant effect on the biological assets of the company.

The R-squared estimate of 0.745 indicates that the model is a good one as about $74.5 \%$ of the total variations in biological assets of Okomu Oil Palm Company Plc can be attributed to fair value accounting of NCA, PAT and CA of the company. The remaining $25.5 \%$ are due to other relevant variables not captured in the model.

The Durbin-Watson statistic value of 1.522128 which is closer to 2 than to zero indicates that the model is free from first order autocorrelation.

\section{Conclusion and Recommendations}

Having explored the impact of fair value accounting on the biological assets of Nigerian agricultural sector with a focus on Okomu Oil Palm Company Plc, it was discovered that fair value accounting operationalized by market value of current assets, profit after tax and current assets have insignificant positive effect on the biological assets of the Company. The researcher therefore concludes that fair value accounting is relevant in keeping records of biological assets of Agricultural sector in Nigeria. Based on these findings, the following recommendations were made:

1) Fair value accounting of non-current assets such as land and building, machine, plant and equipments, amongst others should bemonitored since they help to optimize biological assets in the company.

2) Since the biological assets interacts positively with productivity of the quoted Nigerian agricultural firm, Okomu Oil Palm Company should work towards increasing their commitments into acquiring machines and equipment in order to improve earnings from their business transaction.

3) There is need for agricultural firms to adopt the fair value accounting system in other to keep proper records of its biological assets.

\section{Appendix}

\section{Appendix A: Normality Test}

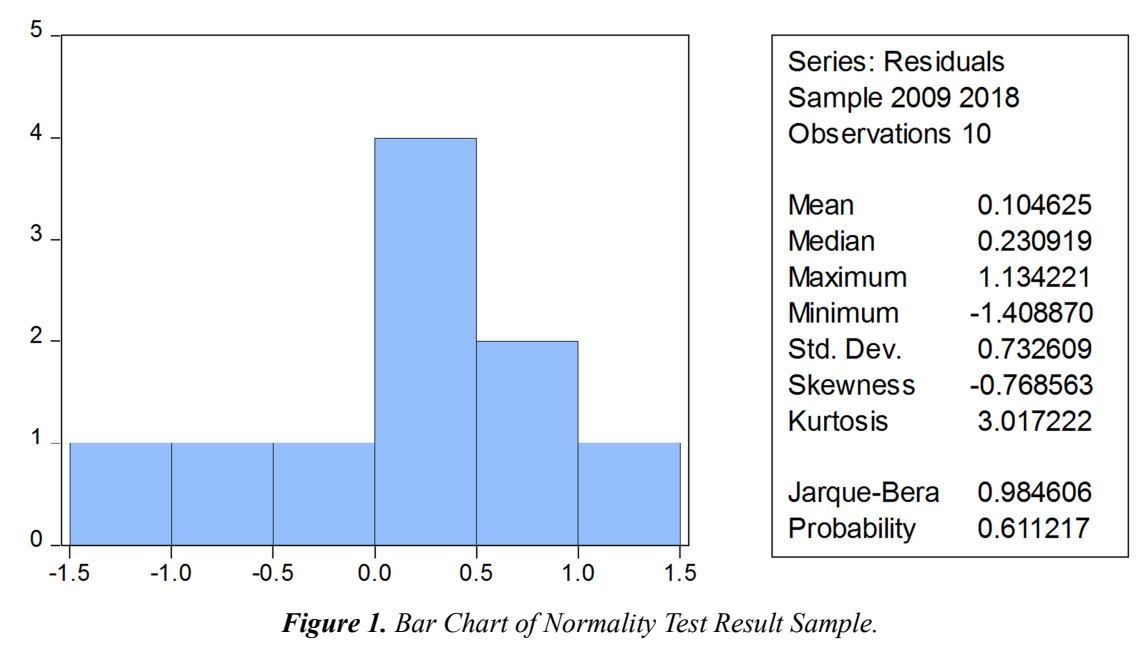


Appendix B: Heteroskedasticity Test

Table 6. Heteroskedasticity Test.

\begin{tabular}{|c|c|c|c|c|}
\hline \multicolumn{5}{|c|}{ Heteroskedasticity Test: Breusch-Pagan-Godfrey } \\
\hline F-statistic & 1.889485 & \multicolumn{2}{|l|}{ Prob. F(3,6) } & 0.2324 \\
\hline Obs*R-squared & 4.857930 & \multicolumn{2}{|l|}{ Prob. Chi-Square(3) } & 0.1825 \\
\hline Scaled explained SS & 0.611315 & \multicolumn{2}{|l|}{ Prob. Chi-Square(3) } & 0.8938 \\
\hline \multicolumn{5}{|l|}{ Test Equation: } \\
\hline \multicolumn{5}{|c|}{ Dependent Variable: RESID`2 } \\
\hline \multicolumn{5}{|c|}{ Method: Least Squares } \\
\hline \multicolumn{5}{|c|}{ Date: 04/19/19 Time: 23:45 } \\
\hline \multicolumn{5}{|c|}{ Sample: 20092018} \\
\hline \multicolumn{5}{|c|}{ Included observations: 10} \\
\hline Variable & Coefficient & Std. Error & t-Statistic & Prob. \\
\hline $\mathrm{C}$ & -5.137339 & 5.299952 & -0.969318 & 0.3698 \\
\hline LOG(NCA) & 0.290438 & 0.164421 & 1.766427 & 0.1278 \\
\hline LOG(PAT) & -0.499912 & 0.263326 & -1.898455 & 0.1064 \\
\hline $\mathrm{LOG}(\mathrm{CA})$ & 0.557695 & 0.334896 & 1.665277 & 0.1469 \\
\hline R-squared & 0.485793 & Mean dependent var & & 0.493990 \\
\hline Adjusted R-squared & 0.228690 & S.D. dependent var & & 0.653069 \\
\hline S.E. of regression & 0.573553 & Akaike info criterion & & 2.015241 \\
\hline Sum squared resid & 1.973778 & Schwarz criterion & & 2.136275 \\
\hline Log likelihood & -6.076207 & Hannan-Quinn criter. & & 1.882467 \\
\hline F-statistic & 1.889485 & Durbin-Watson stat & & 2.544813 \\
\hline Prob(F-statistic) & 0.232385 & & & \\
\hline
\end{tabular}

\section{References}

[1] Herbohn, K. \&Herbohn, J. (2006). International Accounting Standard (IAS) 41: What are the implications for reporting forest assets? Small-scale Forest Economics, Management and Policy, 5 (2), 175-189.

[2] Gonçalves, R. \& Lopes, P. (2014). Accounting in agriculture: Disclosure practices of listed firms. FEP Working Paper No. 530, 1-31.

[3] Ryan, S. G. (2008). Fair value accounting: Understanding the issues raised by the credit crunch. Council of Institutional Investors, 1-24.

[4] IFRS (2009). A practical guide to accounting for agricultural assets November. Price Water House Coopers Retrieved on March 272019 from https://www.pwc.com/gx/en/ifrsreporting/pdf/a_practical_guide_to_accounting_for_agricultur al_assets.pdf

[5] Sanja, S. M., Ivana, M. S. \&Mateja, B. (2016). Valuation of biological assets under IAS 41 - the case of listed and large companies in Croatia. Research World International Conference, Barcelona, Spain, 44-50.

[6] Amanamah, R. \& Owusu, E. K. (2016). Perception on fair value measurement in Ghana: Evidence from account personnel. African Journal of Applied Research (AJAR), 2 (2), 22-34.

[7] Ashford, C. C. (2011). Fair value accounting: Its impacts on financial reporting and how it can be enhanced to provide more clarity and reliability of information for users of financial statements. International Journal of Business and Social Science, 2 (20), 12-19.

[8] Quagli, A. \& Avallone, F. (2010). Fair value or cost model? Drivers of choice for IAS 40 in the real estate industry. European Accounting Review, 19 (3), 461-493.

[9] Agyemang, J. K., Acheampong, O. \& Akenten, W. N. (2018). Fair value accounting: Implementation challenges facing small and medium-sized entities in the agricultural sector. International Journal of Accounting and Financial Reporting, $8(4), 1-23$.

[10] IASB, International Accounting Standard 41 - Agriculture, EC staff consolidated version as of 16 September 2009. Retrieved from: http://www.iasplus.com/en/standards/ias/ias41 on April $15,2019$.

[11] Bessong, P. K. \& Charles, E. (2012). Comparative analysis of fair value and historical cost accounting on reported Profit: A study of selected manufacturing companies in Nigeria. Research Journal of Finance and Accounting, 3 (8), 132-149.

[12] Cavalheiro, R. T., Kremer, A. M. \& Gimenes, R. M. T. (2017). Fair value for biological assets: an empirical approach. Mediterranean Journal of Social Sciences, 8 (3), 55-68.

[13] Starova, M., Cermakova, H., Hlavsa, T., Vostrovska, M. \& Leva, M. (2016). Evaluation of applicability of IAS 41 Agriculture to the valuation of growing forest stands and their accounting treatment in the Czech Republic. Journal of Forest Science, 62 (9), 429-440.

[14] Dorel, M., Veronica, G., Elena, H., Ionel, B., Ovidiu, B., Aura, D., Maria, M. \&Alin, A. (2015). Biological assets and the agricultural products in the context of the implementation of the IAS 41: A case study of the Romanian agro-food system. Arch. Biol. Sci., Belgrade, 67 (2), 705-714.

[15] Biljon, M. V. (2016). An application guideline for the fair value accounting of biological assets. University of South Africa, 1-315.

[16] Balogun, E. O. (2015). Effect of fair value accounting on asset valuation in Public Limited Companies (A Study of Petroleum Companies in Nigeria). Journal of Accounting and Financial Management, 1 (8), 111-126. 
[17] Kazmouz, B. (2010). The Effect of Applying Fair Value on the Financial Statements of UK Leading Companies. An M.Sc. Dissertation, Department of Accounting and Finance; Arab British Academy for Higher Education.

[18] Alaryan, L. A., Haija, A. A. A. \& Ali, M. A. (2014). The relationship between fair value accounting and presence of manipulation in financial statements. International Journal of Accounting and Financial Reporting, 4 (1), 221-237.

[19] Al-Khadash, H. A. \& Khasawney, A. Y. (2014). The effect of the fair value option under IAS 40 on the volatility of earnings. Journal of Applied Finance \& Banking, 4 (5), 95113.

[20] Elfaki, A. A. A. \& Hammad, S. M. E. (2015). The impact of the application of fair value accounting on the quality of accounting information: An empirical study on a group of companies listed on the Khartoum Stock Exchange. International Journal of Academic Research in Accounting, Finance and Management Sciences, 5 (1), 148-160.

[21] SaadAl-Sakini andHanan Al-Awawdeh (2015). The Effect of Accounting Conservatism and its Impact on the Fair Value of the Corporation: Empirical Study on Jordanian Public JointStock Industrial Companies. International Journal of Business and Social Science, 6 (7), 2015.

[22] Gujarati D. N. and Porter, D. C. (2009). Basic Econometrics. $5^{\text {th }}$ Edition, McGraw-Hill/Irwin, Boston, 400.

[23] International Accounting Standards Board (IASB). 2014a. Technical summary: IAS 41 Agriculture [online]. United Kingdom. Retrieved from: http://www.ifrs.org/IFRSs/Documents/Technical-summaries2014/IAS\%2041.pdf on April 13, 2019. 